\title{
A COMMENT ON THE ROLE OF THE HAGUE CONFERENCE ON PRIVATE INTERNATIONAL LAW
}

\author{
Georges A.L. Droz*
}

Questions of judicial jurisdiction and, in general, of civil procedure were dealt with at the very first session of the Hague Conference on Private International Law in 1893. That session's fourth commission remarked in its report, "This topic is very broad and forms in itself alone a great part of private international law." Although the Netherlands's government memorandum that was distributed with the note calling the Conference in August 1893 addressed, in the procedural area, only the possibility of an international agreement with respect to foreign judgments based upon uniform rules of territorial jurisdiction of the courts, the commission decided that it did not have enough time to reach agreement on judicial jurisdiction. Thus, it limited itself, for the moment, to preparing a draft agreement on service of judicial documents and on the execution of letters of request. Despite the fact that the original program for the Conference's first session was heavily weighted with family law and general principles of the conflict of laws, articles on service of process and taking of evidence abroad were the first to be drafted. These articles, with the addition of chapters on deposits for costs, legal aid, and physical detention of foreign debtors, formed the nucleus of the first Hague Convention to be fully drafted and to enter into force. The package as a whole, referred to as the Convention on Civil Procedure with additional Protocol, was adopted in the final act of the Conference's second session in 1894. It was signed November 14, 1896, and the Convention entered into force on May 23, 1899, coinciding with the first Hague Peace Conference.

This first successful Hague Convention, ratified by fourteen European countries ranging from Portugal to Russia and from Norway to Romania, laid the groundwork for the conclusion of five family law Conventions at the Conference's third and fourth sessions in 1900 and 1904. Also, a revised version of the Convention on Civil Procedure was signed on July 17, 1905. The 1905 version of this Convention remains in force today, controlling relations between countries that have not both ratified the Civil Procedure Convention of March 1,1954 . This 1954 Convention $^{2}$ remains in force among thirty countries. Its chapters on service of documents abroad and on the taking of evidence abroad were replaced, however, by the 1965 and 1970 Conventions, respectively, and

\footnotetext{
Copyright (C 1994 by Law and Contemporary Problems

* Secretary General of the Hague Conference on Private International Law.

1. Actes de la Première Session de la Conférence de La Haye de Droit International Privé, 1893, at 63 (quotations translated from the original French).

2. 286 U.N.T.S. 265.
} 
therefore govern relations between countries that have ratified both Conventions. Thus, for almost a century, there has been a remarkable continuity to the Conference's work in the field of civil procedure.

The modern Conventions have broken down the subject matter of international civil procedure into three separate Conventions covering service of documents abroad (the 1965 Convention), taking of evidence abroad (the 1970 Convention), and-lumped together-legal aid, deposits for costs, safe conduct of witnesses, and detention of foreign debtors (1980 Convention on International Access to Justice). ${ }^{3}$ The mechanisms of these Conventions, however, have changed dramatically, and the creaky diplomatic and consular channels ${ }^{4}$ are hardly used.

These three "modern" Conventions reflect a determined effort on the part of the Conference to build a bridge between countries having civil law procedural systems (that is, the countries that are parties to the Civil Procedure Convention of 1954) and common law countries, the latter having become more numerous and influential within the Conference since the entry of the United States in 1964. The shift from diplomatic and consular channels to judicial and administrative channels through the creation of the "central authority" mechanism, however, was dictated by the growth in international civil procedural traffic following World War II. Thus, it was not exclusively a common law oriented phenomenon. On the other hand, both the 1965 and the 1970 Conventions include important provisions that are precisely tailored to meet the requirements of common law countries, in particular the United States. For example, the 1896, 1905, and 1954 Conventions contain no equivalents to Articles 15 and 16 of the 1965 Convention. Article 15 tracks closely the requirement of due process of law enunciated in the Fifth and Fourteenth Amendments to the Constitution of the United States. It forbids the court to issue a judgment against a defendant who has not appeared, unless this article's standard of "international procedural due process of law" has been met. Article 16 sets out the conditions for a bill of review, which allows a defendant who has failed to appear to reopen a default judgment upon showing due cause to do so. This provision approaches being an international rule of substantive due process of law. These two provisions serve to protect U.S. defendants against injustice that might occur in a lawsuit filed in the courts of any of the other twenty-eight countries that are party to the Convention.

Aside from providing due process of law for defaulting defendants, the Hague Service Convention provides several channels for effectuating service

3. Convention on the Service Abroad of Judicial and Extrajudicial Documents in Civil or Commercial Matters, opened for signature Nov. 15, 1965, art. 2, 20 U.S.T. 361, 658 U.N.T.S. 163 [hereinafter Hague Service Convention]; Convention on the Taking of Evidence Abroad in Civil or Commercial Matters, opened for signature Mar. 18, 1970, art. 2, 23 U.S.T. 2555, 847 U.N.T.S. 231 [hereinafter Hague Evidence Convention]; Convention on International Access to Justice, Oct. 25, 1980, 19 I.L.M. 1505.

4. Id. See, e.g., Practical Handbook on the Operation of the Hague Convention of 15 NOVEMBER 1965 ON THE SERVICE ABROAD OF JUdiCIAL AND EXTRAJUdicial DOCUMENTS IN Civil or Commercial Matters 34, 41 (2d ed. 1992) [hereinafter Practical HaNdbook]. 
abroad. Each contracting party commits itself to designate a Central Authority and to effectuate and return service through that Central Authority when requested to do so, subject only to the highly unusual exceptions-infringement of its sovereignty or security-set out in Article 13. This system represents a change from that which existed in the absence of the treaty, in which no country was required by international law to effectuate service on its territory or to allow any person to effectuate service on its territory. Service made through the Central Authority is free of charge to the requesting party, unless a judicial officer or other process server has to be employed, or the particular method of service requested by the applicant entails unusual costs. ${ }^{5}$ The system of the receiving Central Authority is faster and generally less expensive to employ than the traditional diplomatic channels. Also, the system is compulsory for the requested state and does not depend upon that state's willingness to exercise "comity" in order to effectuate service. The Central Authorities of the twentynine contracting parties routinely receive, execute, and return requests for service in hundreds of cases every year. This process is made routine by the mandatory forms that have been incorporated into the Hague Service Convention.

The Hague Evidence Convention, second in line of the modern set of "procedural" Conventions, has a more flexible structure because the operation it is intended to carry out - the taking of evidence abroad-is not so routine as the effectuation of service. Here also, there are other possible options besides the regular channel through the Central Authority. A very important concession to the deposition practice of the United States was made in chapter II of the Convention through the inclusion of provisions for the taking of voluntary evidence by a commissioner appointed by the requesting court. Under this provision, even countries where the law provides that the taking of evidence for lawsuits is a judicial function that can be carried out only by a magistrate regularly allow the taking of voluntary evidence by a commissioner. If the testimony or other evidence-taking cannot be arranged voluntarily, it can be obtained compulsorily by directing a letter of request to the Central Authority of the country where the evidence is to be taken. ${ }^{6}$

Evidence-taking procedures in other countries may generally be conformed to U.S. practice. For example, when France adopted its new Code of Civil Procedure following its ratification of the Hague Evidence Convention, special provisions were included to allow, in connection with international letters of request, cross-examination of witnesses and the taking of a verbatim transcript of the testimony. Neither of these practices is permitted in domestic French civil procedure, under which the magistrate normally poses the questions and summarizes the testimony. The sticky question of privilege is addressed in Article 11 of the Convention by giving the witness the privileges he or she has under the law of the state where the testimony is taken, and also those he or

5. Hague Service Convention, supra note 3, art. 12.

6. Hague Evidence Convention, supra note 3, art. 22. 
she has under the law of the requesting state, insofar as the privilege has been specified in the letter of request or otherwise confirmed to the requested authority by the requesting authority.

The shift of civil procedural traffic, that is, requests for service of process and taking of evidence abroad, from diplomatic channels to administrative/judicial channels with specifically designated Central Authorities, has resulted in better delineation of the responsibility for these activities. Although handling this traffic is very important to litigants and their lawyers, governmental bureaucracies sometimes fail to recognize this importance. Eight years after the Hague Service Convention came into force between the United States, the United Kingdom, and the Arab Republic of Egypt, the Permanent Bureau of the Hague Conference organized a meeting to review and discuss its operation. The special commission met in November 1977 and found that the Convention was working well overall, but that there were some discrepancies in the way it was operating in different countries. The special commission, therefore, sought to reduce those discrepancies. Notably, several countries subsequently reduced or eliminated fees that were not within the spirit of Article 12 of the Convention. ${ }^{7}$ In some cases, these fees were a burden on the efficiency of the system, not so much because of their amount, but because of the difficulty experienced in determining the amount of and obtaining a check for payment in a foreign currency.

Most of the participants in that first special commission meeting, as well as the one that followed in June 1978 concerning the Hague Evidence Convention, were the governmental lawyers or administrators who operated the Central Authorities. A somewhat unexpected spin-off benefit from these meetings was what I have called the "incarnation" 8 of the Central Authorities, a term meant to refer to the fact that these lawyers and administrators were no longer faceless bureaucrats to one another. Instead, they were real people, struggling conscientiously to service the needs of the litigating public.

At the second meeting, the sticky issue was, on one side, U.S.-style discovery and, on the other side, broad reservations made under Article 23 of the Evidence Convention. ${ }^{9}$ The discussions could not bridge the gap between these two extremes. That the United Kingdom had limited the scope of its own Article 23 reservation from the time of its initial ratification of the Convention, however, clearly demonstrated that the reservation permitted by Article 23 had been drafted too broadly. The special commission formally recommended that

7. See Practical HaNdBoOK, supra note 4, at 37.

8. See Georges A.L. Droz, Evolution du röle des autorités administratives dans les Conventions de droit international privé au cours du premier siècle de la Conférence de La Haye, in ETUDES OFFERTES A PIERRE Bellet 142-43 (Litec, 1991).

9. Article 23 of the Convention reads as follows:

A Contracting State may at the time of signature, ratification or accession declare that it will not execute Letters of Request issued for the purpose of obtaining pre-trial discovery of documents as known in Common Law countries.

Hague Evidence Convention, supra note 3, art. 23. 
countries that had taken the Article 23 reservation and those who may take it in the future should limit its scope by following the U.K. example.

The "incarnation" of the Central Authorities led to a desire to have a publication that would consolidate the results of the discussions and serve to facilitate better communication in the future. To meet this wish, the Permanent Bureau published in 1983 and 1984, respectively, practical handbooks on the Service and Evidence Conventions, which pull together detailed information on the practices of the states' Central Authorities, as well as more general information on the main issues arising under the Conventions and on case law from different countries dealing with those issues. Keeping these publications up to date has been somewhat difficult for the Permanent Bureau because of its small staff, but the revised second edition of the Practical Handbook on the Service Convention was delivered by the printers in the fall of 1992 and is now available to users of the Convention. ${ }^{10}$

After the special commission meetings of 1977 and 1978, the Hague Conference undertook to complete the piecemeal revision of the general Convention on Civil Procedure of 1954 by preparing a new convention incorporating provisions on legal aid in the multinational context, security for costs and enforceability of orders for costs, copies of entries from official records and court decisions, physical detention of foreign debtors, and safe conduct of witnesses. This treaty, entitled "Convention on International Access to Justice," was completed at the Conference's fourteenth plenary session in 1980 , and is presently in force among a number of European countries. ${ }^{11}$ The United States, lacking a comprehensive national legal aid system, has not shown any interest in ratifying this Convention thus far, even though its federal system does not seem to bar ratification. The treaty implies that the territories covered have some system of legal aid already in place; thus, if the United States ratifies it at all, it might do so only for those states that have a recognizable system of legal aid already in force. This treaty also has a system of Central Authorities, but, unlike those created under the Service and Evidence Conventions, these authorities may receive applications for transmission to the Central Authority in the state where the legal proceeding is pending, as well as receive and act upon applications. They are thus "two-way" Central Authorities, exercising both receiving and transmitting functions at the international level.

The process of two-way communication between Central Authorities is best illustrated by a convention that was completed at the Hague Conference's fourteenth session: the Convention on the Civil Aspects of International Child Abduction. ${ }^{12}$ This treaty, although primarily intended to deal with custody disputes, is basically procedural in nature, and is not intended to resolve custody disputes on their merits. The narrower issue posed by this convention is whether a child will be returned immediately following a wrongful removal or

10. See supra note 4.

11. Oct. 25, 1980, 19 I.L.M. 1505.

12. Oct. 25, 1980, 1343 U.N.T.S. 89, 19 I.L.M. 1501. 
retention. This process requires rapidity in order to match the needs of a child's sense of time. Two-way Central Authorities are therefore designated under the Convention in order to assure rapid and accurate communication. These Central Authorities become truly "incarnated" in that they are asked by the Permanent Bureau to give up their bureaucratic anonymity, identifying not only their telephone and telefax numbers, but also the names of contact persons and the languages they speak or understand. The Permanent Bureau regularly circulates information on recent changes in the Central Authorities in order to facilitate their communication with each other in every way. A special commission meeting was held in October of 1989 to review the operation of this convention in practice; a second meeting took place in January of $1993 .{ }^{13}$

In April of 1989, another special commission meeting was held to review the operation of the Service and Evidence Conventions. ${ }^{14}$ This process of "monitoring" the operation of conventions involving international judicial cooperation and Central Authorities has become an increasingly important part of the Permanent Bureau's work over the last fifteen years. The United States plays an important role in this activity since three of the four Hague Conventions joined by the United States are conventions that involve a cooperative Central Authority.

Before I close, perhaps I should say a few words about the famous cases in the United States under the Hague Conventions, notably two cases in which the United States Supreme Court ruled on the scope of application of, respectively, the Service' and Evidence Conventions. ${ }^{15}$ In Sociéte Nationale Industrielle Aérospatiale v. United States District Court for the Southern District of Iowa, ${ }^{16}$ the Court had to delineate the scope of application of the Evidence Convention as against that of the Federal Rules of Civil Procedure. The Court took a middle ground, ruling that the treaty did not preempt the domestic rules as suggested by some of the amicus curiae briefs filed by other states participating in the convention, but also finding that the convention was more than a mere supplement to the Federal Rules of Civil Procedure. ${ }^{17}$ This view had been suggested by the United States Court of Appeals for the Eighth Circuit in its opinion in Aérospatiale ${ }^{18}$ and by the United States Court of Appeals for the Fifth Circuit in In re Anschuetz ${ }^{19}$ and In re Messerschmitt Bolkow Blohm. ${ }^{20}$ All nine Justices of the United States Supreme Court thus managed to avoid the extreme positions.

13. See Report of the Second Special Commission Meeting to Review the Operation of the Hague Convention on the Civil Aspects of International Child Abduction, 35 I.L.M. 225 (1994).

14. See Report of the Special Commission of 1989, 28 I.L.M. 1556 (1989).

15. Société Natioinale Industrielle Aérospatiale v. United States Dist. Ct. for the So. Dist. of Iowa, 428 U.S. 522 (1987) (Evidence Convention); Volkswagenwerk Aktiengesellschaft v. Schlunk, 486 U.S. 694 (1988) (Service Convention).

16. 428 U.S. 522 (1987).

17. $I d$. at $529-40$.

18. 82 F.2d 120 (8th Cir. 1986).

19. 754 F.2d 602 (5th Cir. 1985).

20. 757 F.2d 729 (5th Cir. 1985). 
The "comity analysis" proposed by the majority in Aérospatiale is somewhat confusing to jurists whose roots are not in the U.S. legal system. The minority of the Supreme Court suggested that the necessary comity analysis had already taken place in the negotiation and drafting stages of the Evidence Convention. However, as I previously. indicated, the special commission of June 1978 concluded that the reservation of Article 23 was drawn too broadly, and the special commission that met in May of 1985 to consider the operation of the Evidence Convention reconfirmed this conclusion. ${ }^{21}$ Even though the recommendation of the 1978 special commission-that the reservations be limited by declaration-was followed by a number of countries, including all of Scandinavia, ${ }^{22}$ the Netherlands, and Mexico, certain important countries have not done so. France, which had always had a liberal practice within the framework of its Article 23 declaration, formally limited it by declaration deposited at the Hague Conference only while the case was pending before the United States Supreme Court ${ }^{23}$ Germany still has not limited its declaration.

With a few notable exceptions, the tendency of the trial courts since Aérospatiale seems to be to order use of the Federal Rules of Civil Procedure rather than the Evidence Convention. While the Permanent Bureau may regret this, the regret is not simply because of loss of influence or "turf." It is because the Permanent Bureau feels that the convention truly reflects a multinational "comity analysis" that should facilitate international evidence-taking with a minimum of friction. I do not take a position here as to whether it may be necessary to negotiate a protocol to the Evidence Convention or even to revise that Convention in order to close the gap between legitimate U.S. aspirations for obtaining evidence abroad and the scope of the reservations taken by other countries under Article 23. At the special commission meeting on future work and policy of the Conference, held at the Hague Conference in June 1992, no pressing requests came forward from any of the member states either for revision of the Evidence Convention or for a further meeting to review its operation. ${ }^{24}$ Nonetheless, such possibilities remain open, and the Permanent Bureau is receptive to any initiatives which may come from member states seeking to improve the operation of this Convention in practice.

21. See Report of the 1978 Special Commission, 17 I.L.M. 1425 (1978); Report of the 1985 Special Commission, 24 I.L.M. 1668, 1678 (1985).

22. See Practical handbook on the Operation of the Hague Convention of 18 March 1970 on tHE TAKING OF EVIDENCE ABROAD IN CIVIL OR COMMERCIAL MATTERS 51-52, 54, 82-83, 90-91 (1984).

23. The French declaration, deposited on January 19, 1987, reads as follows:

The declaration made by the French Republic in accordance with Article 23 relating to Letters of Request issued for the purpose of obtaining pre-trial discovery of documents does not apply when the requested documents are enumerated limitatively in the Letter of Request and have a direct and precise link with the object of the procedure.

(Translation of the French text.)

24. See Permanent Bureau, Conclusions of the Special Commission of June 1992 on General Affairs and POlicy of THE CONFERENCE 19 (Preliminary Doc. No. 18, Aug. 1992) (for the attention of the Seventeenth Session). 
The other major decision of the United States Supreme Court concerning the application of a Hague convention was Volkswagenwerk Aktiengesellschaft v. Schlunk. ${ }^{25}$ The "piercing of the corporate veil" in this case was shocking to some jurists from civil law systems. However, the basic principle applied by the Supreme Court - that it is up to the local law to determine whether a document has to be transmitted abroad for service-should not have been so surprising, since the Supreme Court of at least one continental European country, the Netherlands, had already endorsed the same principle. So far as I am aware, the concern expressed by the concurring justices in Schlunk that this decision might be taken in other countries as encouragement to revive the abuses of the notification à parquet system, which the Service Convention was supposed to remedy, has not proved justified. Also, most of the other forty-nine U.S. states take a more rigorous view of the requirements for piercing the corporate veil in connection with service of process than did the courts of Illinois in Schlunk. All countries have some concepts that fall within the framework of "agency," as it is known in common law. Only if the concept of agency were stretched so far as to eliminate recourse to the Convention on a broad basis would a serious danger to the Convention's application arise.

The Service Convention, like the Evidence Convention, is intended to facilitate the work of practicing lawyers and judges, while protecting the legitimate concerns of defendants and witnesses. ${ }^{26}$ Both create secure and relatively efficient administrative means for giving notice of lawsuits and fleshing out those lawsuits with useful evidence. As the results of negotiation and compromise, these Conventions of course are not perfect instruments. However, they offer a means of cooperation to deal with multinational obstacles to achieving the legitimate procedural aims of lawsuits. Service of process and taking of evidence are simply two important steps in the push toward the ultimate aim of lawsuits: to obtain a settlement or enforceable judgment. If procedural cooperation did not exist at the levels provided by the Hague Service and Evidence Conventions, it would be difficult to imagine achieving international cooperation on the recognition and enforcement of judgments. Indeed, as proof of this cooperation, the European Community ("EC") in the Brussels Convention of September 27, 1968, by including Article 20, took the almost unprecedented step of deferring in that organization's convention to the convention of another organization. ${ }^{27}$ Article 15 of the Hague Service Convention replaces the second paragraph of Article 20 of the Brussels $^{28} /$ Lugano/San Sebastian Conventions in relations between two countries

25. 486 U.S. 694 (1988).

26. Hague Service Convention, supra note 3.

27. Convention on Jurisdiction and Enforcement of Judgments in Civil and Commercial Matters (first English version published with the Convention of Accession of Oct. 9, 1978 of the Kingdom of Denmark, of Ireland, and of the United Kingdom of Great Britain and Northern Ireland) L 304, in 21 OFFICIAL JOURNAL OF THE EUROPEAN COMMUNITIES, Oct. 30, 1978, at 36.

28. The English version of the 1968 Brussels Convention as revised by the 1978 Accession Convention was published in 21 OFFICIAL JOURNAL OF THE EUROPEAN COMMUNITIES, supra note 27 , at 77 . 
that have both ratified the Hague Service Convention. The EC has pushed to have all members of that organization ratify these two Hague Conventions; all but Ireland have ratified the Service Convention, ${ }^{29}$ and all but Belgium, Greece, and Ireland have ratified the Evidence Convention. The success of the Brussels Convention system, as is now indicated by its extension to the European Free Trade Area ("EFTA") countries in the Lugano Convention, ${ }^{30}$ owes something to these parallel networks of cooperation among the EC countries, created by the ratification of the Hague Service and Evidence Conventions.

The papers submitted to this symposium under the heading "Foreign Judgments: The Case for a New Treaty," deal with a logical extension of the cooperation created under conventions on service of process and taking of evidence, an extension that would have no underlying foundation on which to support itself if there were no basic instruments of international procedural cooperation. ${ }^{31}$ The proposal by the United States, that the Hague Conference on Private International Law take up work on a new treaty on enforcement of judgments, draws its credibility from the existing participation by the United States in international judicial cooperation under the Hague Service, Evidence, and Child Abduction Conventions.

The collection of articles published in this special issue of Law and Contemporary Problems will form a worthy contribution to the study of international problems of civil procedure. The American Bar Association's litigation section and the Private Adjudication Center of Duke University School of Law, by their co-sponsorship of this symposium, have offered a much appreciated celebration of the Hague Conference's centennial. The symposium issue highlights the continuing importance of the Conference's role in alleviating international procedural problems.

29. N.B. Ireland ratified the Service Convention on April 5, 1994. This treaty is therefore in force throughout the European Union.

30. Article 20 remains the same in all versions of this treaty, including the 1988 Lugano Convention, which is intended to apply among EC and EFTA member states, and the 1989 San Sebastian Convention, which extends the 1968 Brussels convention, as amended, to Spain and Portugal (the newest members of the EC).

31. Andreas F. Lowenfeld, Thoughts About a Multinational Judgments Convention: A Reaction to the von Mehren Report, 57 LAW \& CONTEMP. ProbS. 289 (Summer 1994); Arthur T. von Mehren, Recognition and Enforcement of Foreign Judgments: A New Approach for the Hague Conference?, 57 LAW \& CONTEMP. PRobS. 271 (Summer 1994). 
